\title{
DNA Barcoding analysis of seafood accuracy in Washington, DC restaurants
}

\author{
David B Stern ${ }^{1}$, Eduardo Castro Nallar ${ }^{2}$, Jason Rathod ${ }^{3}$, Keith A Crandall ${ }^{\text {Corresp. }{ }^{1,4}}$ \\ ${ }^{1}$ Computational Biology Institute, Milken Institute School of Public Health, George Washington University, Washington, DC, USA \\ 2 Center for Bioinformatics and Integrative Biology, Universidad Andrés Bello, Santiago, Chile \\ 3 Migliaccio \& Rathod LLP, Washington, DC, USA \\ 4 Department of Invertebrate Zoology, Smithsonian Institution, Washington, DC, USA \\ Corresponding Author: Keith A Crandall \\ Email address: kcrandall@gwu.edu
}

In Washington DC, recent legislation authorizes citizens to test if products are properly represented and, if they are not, to bring a lawsuit for the benefit of the general public. Recent studies revealing the widespread phenomenon of seafood substitution across the United States make it a fertile area for consumer protection testing. DNA barcoding provides an accurate and cost-effective way to perform these tests, especially when tissue alone is available making species identification based on morphology impossible. In this study, we sequenced the 5' barcoding region of the Cytochrome Oxidase I gene for 12 samples of vertebrate and invertebrate food items across six restaurants in Washington, DC and used multiple analytical methods to make identifications. These samples included several ambiguous menu listings, sequences with little genetic variation across closely related species and one sequence with no available reference sequence. Despite these challenges, we were able to make identifications for all samples and found that $33 \%$ were potentially mislabeled. Despite this high degree of mislabeling, the errors involved closely related species and we did not identify egregious substitutions as have been found in other cities. This study highlights the efficacy of DNA barcoding and robust analyses in identifying seafood items for consumer protection. 
1 DNA Barcoding analysis of seafood accuracy in Washington, DC restaurants

2 David B. Stern ${ }^{1}$, Eduardo Castro-Nallar ${ }^{2}$, Jason Rathod ${ }^{3}$, and Keith A. Crandall ${ }^{1,4}$

$4 \quad{ }^{1}$ Computational Biology Institute, Milken Institute School of Public Health, The George

5 Washington University, Washington, DC, USA

$6{ }^{2}$ Center for Bioinformatics and Integrative Biology, Universidad Andrés Bello, Santiago, Chile

$7 \quad{ }^{3}$ Migliaccio \& Rathod LLP, Washington, DC, USA

$8{ }^{4}$ Department of Invertebrate Zoology, Smithsonian Institution, Washington, DC, USA

9

10 Corresponding Author:

11 Keith A. Crandall, $\mathrm{PhD}$

12 Computational Biology Institute

13 George Washington University

$1480022^{\text {nd }}$ Street, NW

15 Washington, DC 20052

16 kcrandall@gwu.edu 


\section{$27 \quad$ Abstract}

28 In Washington DC, recent legislation authorizes citizens to test if products are properly

29 represented and, if they are not, to bring a lawsuit for the benefit of the general public. Recent

30 studies revealing the widespread phenomenon of seafood substitution across the United States

31 make it a fertile area for consumer protection testing. DNA barcoding provides an accurate and

32 cost-effective way to perform these tests, especially when tissue alone is available making species

33 identification based on morphology impossible. In this study, we sequenced the 5' barcoding

34 region of the Cytochrome Oxidase I gene for 12 samples of vertebrate and invertebrate food items

35 across six restaurants in Washington, DC and used multiple analytical methods to make

36 identifications. These samples included several ambiguous menu listings, sequences with little

37 genetic variation across closely related species and one sequence with no available reference

38 sequence. Despite these challenges, we were able to make identifications for all samples and

39 found that $33 \%$ were potentially mislabeled. Despite this high degree of mislabeling, the errors

40 involved closely related species and we did not identify egregious substitutions as have been

41 found in other cities. This study highlights the efficacy of DNA barcoding and robust analyses in

42 identifying seafood items for consumer protection. 


\section{Introduction}

54 Seafood products are some of the most frequently mislabeled and misrepresented food

55 items across the globe. The DNA-based investigation by Oceana, taking place from 2011 to 2013,

56 revealed that nearly $33 \%$ of seafood is mislabeled in retail outlets (Warner et al. 2013). Snapper,

57 tuna, and shrimp were the most frequently substituted and often were replaced with species

58 carrying health advisories or of conservation concern (Warner et al. 2013). State and federal

59 consumer protection laws prohibit food mislabeling of this kind. One of the strongest such laws is

60 Washington DC's Consumer Protection Procedures Act ("CPPA"). The CPPA is remarkably

61 comprehensive in its protections of consumers and includes expansive remedies if the law is

62 violated. Specifically, the statute allows for individuals to purchase goods for the express

63 purpose of testing their contents to determine whether they comport with the DCCPA. It is illegal

64 under the DCCPA to "represent that goods or services have a source, sponsorship, approval,

65 certification, accessories, characteristics, ingredients, uses, benefits, or quantities that they do not

66 have" (D.C. Code $\S 28-3904)$. Violations of the DCCPA entitle plaintiffs to $\$ 1500$ in statutory

67 damages per violation and the ability to recover not just for themselves, but on behalf of the

68 general public, enabling citizens to act as "private attorneys general" (Rubenstein 2004).

69 DNA barcoding is a particularly useful tool for making species-level identifications when

70 other data (morphological, geographical, ecological, etc.) are not available or may mislead

71 identifications. The 5' end of the Cytochrome Oxidase I (COI) mitochondrial gene has been

72 established as the "barcode" sequence for metazoan taxa due to its high variability and

73 conservation of PCR primer sites (Hebert et al. 2003). Due to the efforts of biologists around the

74 world, there is a large database of barcode DNA sequences from 260,654 species of animals,

75 plants, fungi and other life (Barcode of Life Database, http://www.boldsystems.org/, Accessed

76 December 1, 2016), facilitating identification. The approach has been proven to be a valuable

77 forensic tool in identifying substitution in the seafood market (Ardura et al. 2010; Hanner et al.

78 2011; Lowenstein et al. 2009; Torres et al. 2013; Vandamme et al. 2016; Wong \& Hanner 2008), 
79 as well as identifying seafood that carry conservation and human health concerns (Lowenstein et

80 al. 2010). Although sophisticated uses of DNA barcoding exist to characterize large dataset of

81 DNA barcodes, (e.g Brown et al. 2012; Zhang et al. 2012), a typical barcoding analysis consists

82 of querying a sampled sequence against a database such as the National Center for Biotechnology

83 Information (NCBI) GenBank or BOLD using BLAST (Altschul et al. 1990; Altschul et al. 1997)

84 or a similar algorithm. The potential pitfalls of using this method to identify species have been

85 explored and include sequencing errors, lack of variation in the barcode marker, incorrect

86 identification of voucher sequences, arbitrary similarity cutoffs, unavailability of references and

87 accidental sequencing of nuclear mitochondrial genes, in addition to methodological and

88 theoretical shortcomings (Collins \& Cruickshank 2013).

89 Even beyond seafood and species identification, phylogenetic methods have a history of

90 use in US court cases (e.g. Metzker et al. 2002). For our purposes, phylogenetics presents a

91 potential to increase and supplement the strength of similarity-based identifications by setting the

92 tests in a statistical framework (Huelsenbeck \& Crandall 1997). When 100\% identical matches

93 are not found or when multiple reference sequences are similarly distant from the query,

94 phylogenetic topology tests can garner statistical support to reject alternative hypotheses. We can

95 test a priori hypotheses based solely on the labeling of the seafood item, or test if an

96 identification made by some other method is significantly better than a competing one.

97 In this study, as part of a preliminary legal investigation exploring the viability of a

98 lawsuit under Washington DC's CPPA, we sample the barcoding region of the COI gene to test

99 the identity of commonly mislabeled seafood products from six restaurants in Washington, DC.

100 We take multiple approaches to identify the sampled specimens. While we report multiple

101 potentially mislabeled food items, the majority of our tested items were either correctly labeled or

102 were identified as legally acceptable species for the food labeling.

103

104 Materials and Methods 
106 Six restaurants in Washington, DC (Table 1) were visited in March of 2015. Two seafood

107 dishes were sampled from each restaurant, targeting menu-listings with potential human health or

108 conservation concerns. One tissue sample per menu item was stored in 95\% ethanol. Care was

109 taken to only collect tissue from the main dish from the center of the food item after rinsing away

110 other substances. Total DNA from each sample was extracted with the Qiagen DNeasy DNA

111 extraction kit. PCR amplification of COI was performed using the LCO1490/HCO2198 (Folmer

112 et al. 1994) primers for invertebrate species and FishF2_t1/FishR2_t1 (Ivanova et al. 2007) for

113 vertebrate species. $25 \mu \mathrm{l}$ PCR reactions contained $2.5 \mu \mathrm{l}$ 10X PCR Buffer, $0.75 \mu 150 \mathrm{mM} \mathrm{MgCl}$,

$1140.5 \mu \mathrm{l} 10 \mathrm{mM}$ dNTPs, $0.5 \mu \mathrm{l} 10 \mu \mathrm{M}$ forward primer, $0.5 \mu \mathrm{l} 10 \mu \mathrm{M}$ reverse primer, $0.1 \mu$ l Platinum

115 Taq DNA Polymerase (Thermo Fisher Scientific, Waltham, MA) and $1 \mu$ DNA template. After

116 initial denaturation step of $95^{\circ} \mathrm{C}$ for five minutes, PCR took place in 35 cycles of $95^{\circ}$ for 30

117 seconds, $50^{\circ}$ for 45 seconds and $72^{\circ}$ for 60 seconds with a final extension of $72^{\circ}$ for five minutes.

118 PCR products were cleaned with ExoSAP-IT (Affymetrix, Santa Clara, CA). Each product was

119 sequenced in both directions using the Big Dye (Life Technologies) cycle sequencing protocol

120 and an ABI 3730XL sequencer. We followed Song et al. (2008) to avoid sequencing nuclear

121 copies of COI by checking for high-quality base calls and assuring the absence indels and stop

122 codons in sequence alignments. Sequences have been deposited to NCBI GenBank for public

123 access (Accession numbers: KY656473 - KY656484)

125 Database searches and reference sequence collection

126 Sequences were searched against the Barcode of Life Database

127 (http://www.boldsystems.org) for initial species identification. BOLD contains barcode COI

128 sequences from NCBI as well as from other researchers and institutions who deposit sequences

129 along with species identifications and metadata. We also collected COI sequences from all

130 species present in the top 100 hits of the NCBI BLAST searches and BOLD searches, if available. 
131 Multiple reference COI sequences for the reported species or taxonomic group based on the menu

132 listings were collected from NCBI GenBank. Two types of situations arose in which a proper

133 reference sequence was not available. One was where the menu listing makes reference to a

134 particular species, but a COI sequence was not available on NCBI or BOLD (e.g. Rock Shrimp,

135 Sicyonia brevirostris). In this situation, we collected sequences from related species based on

136 NCBI taxonomy. The other was where the menu listing does not reference one particular species

137 (e.g. Snapper). In this situation, we used only the top BLAST hits from NCBI and BOLD in

138 subsequent analyses.

139

$140 \quad$ Phylogenetic analysis

141 Two alignments were generated, one each for invertebrate and vertebrate sequences.

142 Sequences were aligned using TranslatorX (Abascal et al. 2010) which translates protein-coding

143 sequences to amino acids, aligns protein sequences with MAFFT v7.305b (Katoh \& Standley

144 2013) and then back-translates to nucleotides. This aids in the identification and removal of

145 sequences with premature stop codons and indels that are indicative of numts (Song et al. 2008).

146 Best-fit models of evolution and an optimal data-partitioning scheme were chosen using

147 PartitionFinder v1.1.1 (Lanfear et al. 2012) with each codon position chosen as a priori data

148 subsets and using the Bayesian Information Criterion (BIC) for model selection (Posada \&

149 Crandall 2001). A maximum-likelihood tree was estimated in RAxML 8.2 (Stamatakis 2014)

150 using the partitioning scheme selected with PartitionFinder. 1000 bootstrap replicates were

151 followed by 10 maximum likelihood tree searches under the GTRCAT model with final

152 optimization under GTRGAMMA. We used MrBayes 3.2.2 (Ronquist et al. 2012) to asses the

153 posterior probabilities of nodes recovered in the maximum likelihood estimate using the

154 partitioning scheme and models suggested by PartitionFinder. Four independent runs of four

155 MCMC chains were run for 10,000,000 generations, sampling the cold chain every 1000 steps for

156 a total of 40,000 samples. The first $10 \%$ of samples were discarded as burn-in. Convergence was 
157 assessed by assuring the standard deviation of split frequencies across runs was below 0.01 and

158 that ESS values for all parameters were above 10,000.

160 Topology tests

161 A strength of phylogenetic analysis comes from the ability to compare statistical support

162 for alternative topologies (Huelsenbeck \& Crandall 1997). In this way, we can test alternative $a$

163 priori hypotheses, where appropriate, in which the sampled sequences are constrained to form

164 monophyletic groups with reference sequences or constrained to not form monophyletic groups

165 with those sequences. While monophyly does not equate to identification, strong support against

166 monophyly would suggest that the query sequence is not the same species as the target group. We

167 formed the alternative hypotheses based on the menu listings (Table 2). For example, we were

168 able to test if our Chilean Seabass sequence formed a monophyletic group with other Chilean

169 Seabass sequences, but could only test if "Snapper" formed a monophyletic group with other

170 sequences that could be labeled "Snapper," since the menu listing was not species-specific.

171 Where appropriate, we also tested hypotheses for alternative groupings based on the maximum

172 likelihood phylogeny. In a Bayesian framework, model selection is performed using the Bayes

173 factor, which is the ratio of marginal likelihoods of two competing hypotheses. Marginal

174 likelihoods were estimated for each hypothesis using stepping-stone analysis in MrBayes 3.2.2

175 (Ronquist et al. 2012) with the same models and partitioning scheme as above. Stepping-stone

176 analyses were executed with 4 independent runs of 4 chains each for 50 steps of 200,000

177 generations each (sampled every 1000 generations) each for a total of 10,000,000 generations in

178 each run for each hypothesis. The first step (200,000 generations) was discarded as burn-in. We

179 considered a Bayes factor greater than 5 as strong support for one hypothesis over another (Kass

180 \& Raftery 1995).

181

182 Character-based tests 
184 COI diversity (Ward et al. 2005) potentially as the result of rapid speciation and large effective 185 population sizes that make distance-based identifications challenging (Elias et al. 2007). In this 186 situation, a query sequence can have a nearly identical distance to multiple different reference

187 sequences. While model-based phylogenetic approaches can be effective in this case, we also

188 took advantage of the character-based identification key of Lowenstein et al. (2009) to identify

189 tuna samples. This key consists of 14 nucleotide characters at specific positions across the COI

190 barcoding region developed from an alignment of 87 reference sequences with diagnostic states

191 that are specific to each of the eight tuna species.

\section{Results}

\section{Database searches}

195 BOLD searches were able to make species-level identifications for six of the 12 sampled 196 specimens and genus-level identifications for the other six (Table 1). BOLD did not make 197 species-level identifications for "Australian Barramundi," "Snapper Salsa Verde" or any of the 198 tuna samples. The "Australian Barramundi” sample was a 100\% identical match with Lates 199 uwisara and L. calcarifer. The BOLD records for Lates uwisara linked to GenBank records that 200 were named as L. calcarifer and were therefore treated as L. calcarifer in phylogenetic analyses. 201 Of the six species-level identifications, two did not match the species reported by the restaurants 202 (Table 1). The COI sequence generated from Bobby Van's "Rock Shrimp Tempura" sample 203 matched the Whiteleg shrimp (Litopenaeus vannamei) sequence with 100\% identity (Table 1).

204 The Chilean Seabass sequence from The Oceanaire Seafood Room matched the Antarctic

205 Toothfish (Dissostichus mawsoni) with 100\% similarity.

206 While the labeling of "Gulf shrimp", "Calamari," "Everything Tuna" and "Snapper Salsa

207 Verde" are not species-specific, the "Gulf shrimp" from Gordon Biersch matched

208 Farfantepenaeus aztecus with up to 99.85\% similarity and the "Calamari” from Bobby Van's 
209 Steakhouse matched Uroteuthis edulis with 100\% identity. The "Everything Tuna" sample

210 matched three different tuna species with Thunnus obesus (Bigeye Tuna) as the best hit and

211 "Snapper Salsa Verde" matched three different species in the genus Lutjanus with L. guttatus as

212 the best hit.

213

214 Phylogeny-based tests

215 The final alignments for vertebrate and invertebrate taxa were 699 and 708 bp long,

216 respectively, and contained no gaps. Inspecting placement of query sequences in the maximum

217 likelihood COI trees supported the BOLD identifications with high bootstrap support and

218 posterior probability, except in the case of "tuna" samples, where the phylogeny failed to resolve

219 relationships with high support and numerous species were not monophyletic (Figures $1 \& 2$ ).

220 The failure to resolve a number of species and genera as monophyletic was likely the result of

221 relying on a single mitochondrial marker to estimate a phylogeny of many distantly related

222 groups. This is expected given the numerous biological and methodological reasons that a given

223 gene tree may not match the true "species" tree (Edwards 2009).

224 Bayesian topology tests were able to garner support for identifications where BOLD

225 searches, based on percent similarity, could not (Table 2). Our analysis of Joe's Seafood's “Ahi

226 Tuna" suggested with strong support $(\mathrm{BF}>15)$ that the sequence was not monophyletic with other

227 Ahi (Yellowfin, Thunnus albacares) sequences. The maximum-likelihood phylogeny placed this

228 sequence sister to a clade of six other tuna species and our Bayesian topology test supported its

229 grouping with Albacore tuna (Thunnus alalunga) with strong support over its grouping with

230 Yellowfin/Ahi (BF 25). BOLD analysis suggested that the Yellowfin tuna from Gordon Biersch

231 could have been one of three species (Table 1) and the maximum-likelihood phylogeny narrowed

232 this down to a likely grouping with Yellowfin (T. albacares). The topology test agreed $(\mathrm{BF}=8.36)$

233 that the sequence formed a monophyletic group with other Yellowfin sequences. We found strong

234 support for the hypothesis that our sample from McCormick and Schmick's "Albacore Tuna" did 
235 not form a monophyletic group with the other Albacore (Thunnus alalunga) sequences $(\mathrm{BF}=$

236 20.95). The maximum-likelihood phylogeny placed this sequence sister to a Thunnus albacares

237 sequence and our topology test supported this grouping over Thunnus alalunga $(\mathrm{BF}=24.55)$. The

238 maximum-likelihood phylogeny grouped the "Snapper Salsa Verde" sequence with an

239 assemblage of Lutjanus guttatus and L. synagris. While the topology tests suggested strongly that

240 this sequence grouped with other Lutjanus sequences ( $\mathrm{BF}>55)$, we could not find significant

241 support for its grouping with Lutjanus guttatus or L. synagris over the other $(\mathrm{BF}<1)$.

242 Regardless of the fact that there was no reference COI sequence for Rock Shrimp

243 (Sicyonia brevirostris) available for download, we rejected the hypothesis that this sequence

244 formed a group with other Sicyonia sequences and found strong support for its grouping with the

245 Whiteleg Shrimp (Litopenaeus vannamei, BF>40).

Character-based identification

248 Using the character-based identification scheme of Lowenstein et al. (2009), we were

249 able to make species-level identifications of all of the tuna specimens (Table 3). Only one of the

250 four tuna specimens matched the menu-listed species, although one did not make a species-level

251 listing. The character-based identifications matched our phylogenetic hypotheses in all cases.

\section{Discussion}

254 DNA barcoding is a powerful and cost-effective method for making species-level

255 identifications of seafood items. Here we take advantage of multiple analytical methods (database

256 searches, phylogeny estimate, topology tests, character-based ID) using DNA barcoding to test

257 for seafood substitutions in six restaurants in Washington, DC. Perhaps the clearest act of seafood

258 substitution was the sale of Whiteleg shrimp (Litopenaeus vannemei) as "Rock Shrimp." This was

259 a commonly observed trend in Oceana's 2014 study (Warner et al. 2014). One of the three

260 "Chilean seabass" we tested was identified as Antarctic toothfish, the sister species to the 
261 "Chilean seabass" also known as the "Patagonian toothfish." In general there was agreement, 262 where possible, across multiple methods, and where BOLD was unable to make a species-level 263 identification, another method was able to narrow the identification further. Three of the major 264 issues confronted in this analysis were 1) lack of available reference sequence, 2) ambiguous 265 menu listings, and 3) lack of sequence variation among congeneric species.

266 The lack of available reference sequences was largely an issue that was discovered 267 through database searches and phylogeny estimation. Particularly for the "Rock Shrimp" 268 specimen, there are no available reference COI sequences for Sicyonia brevirostris on GenBank 269 or BOLD. Therefore, we were not able to explicitly test if our sampled "Rock Shrimp" sequence 270 was Sicyonia brevirostris even though BOLD does have sequences from several Sicyonia species 271 including S. brevirostris. It is unfortunate that these are not currently made available to the public 272 especially considering the widespread sale and consumption of "Rock Shrimp" across the country 273 (Warner et al. 2014). We were able to test if our sample belonged to the genus Sicyonia because

274 COI sequences from $S$. carinata and $S$. lancifer were available. Nevertheless, the sequence 275 matched with $100 \%$ identity to the Whiteleg Shimp, Litopenaeus vannamei.

276 Many of the menu listings were vague enough to allow an array of acceptable species.

277 For example, "snapper" can refer to any of the 113 species in the family Lutjanidae or to species

278 from a number of other families with a common name that includes "snapper." "Red snapper" is

279 approved in the US to only refer to the species Lutjanus campechanus and has been involved in a 280 number of cases of seafood fraud (Marko et al. 2004). The phylogenetic analyses strongly 281 supported our sample's placement in the genus Lutjanus, but we were not able to distinguish 282 between an identification of L. guttatus or L. synagris. Either these species are very closely 283 related (resulting in little variation among COI sequences) or reference sequences were not 284 properly identified. Our analyses strongly suggested that the "Calamari" specimen was Uroteuthis 285 edulis, which is one of many squid species approved to be sold as "Calamari" by the FDA 286 (http://www.accessdata.fda.gov, Accessed August 25, 2016). Farfantepenaeus shrimp species 
287 are commercially important with millions of pounds being caught and sold each year (Warner et

288 al. 2014). Farfantepenaeus aztecus, also known as "brown shrimp", is the most widely fished

289 species in the genus. These species are found in the Gulf of Mexico and are therefore often

290 referred to as "Gulf Shrimp."

291 There are eight recognized species in the genus Thunnus, but all can be sold under the

292 name "tuna" or its synonyms in the US according to the FDA (Lowenstein et al. 2009). Database

293 searches and phylogeny estimation failed to make species-level identifications for our "tuna"

294 samples based on the COI sequence. The very low variability among tuna COI sequences has

295 been observed before and results in low support for phylogenetic groupings (Ward et al. 2005).

296 Phylogenetic topology tests did prove more successful in this manner, because we were able to

297 directly compare support for alternative hypotheses, even if the probability of one particular

298 phylogeny or grouping is not objectively high. These results agreed with the character-based

299 identifications, which proved to be the most useful for tuna samples in combination with

300 phylogenetic tests.

301 The "Everything Tuna" sample was identified as Thunnus obesus, which is given a status

302 of "Vulnerable" by the International Union for Conservation of Nature Redlist (IUCN 2015). This

303 was the only one of our samples that was identified as a species with a potential conservation

304 concern. This was certainly lower than the rate of threatened or endangered species found in other

305 cities that have been surveyed, although we did not test grouper, halibut or eel samples, which are

306 frequently substituted with fish from threatened populations (Vandamme et al. 2016; Warner et

307 al. 2013). While none of the substituted seafood items we found carry well-known health risks or

308 conservation concerns per se, the labeling of farmed Whiteleg Shrimp as "Rock Shrimp" is

309 worrisome as wild-caught shrimp are not required to be screened for veterinary drug residue

310 levels like farmed shrimp (FDA 2011).

311

312 Conclusions 
314 Seabass," two "Tuna" and one "Rock Shrimp," were potentially mislabeled, albeit with species

315 that are either closely related or typically considered acceptable for the menu listing. This is

316 consistent with the $33 \%$ average rate found across United States cities by Oceana and lower than

317 seven of the 12 cities surveyed in that study (although higher than the $26 \%$ found in Washington,

318 DC by Oceana in 2013) (Warner et al. 2013).

319 As always, these results rely on the quality of the reference database used, especially the

320 identification of voucher specimens for reference sequences. The potential mislabeling we

321 identified here requires further investigation in order to pinpoint the source of the substitution.

322 Our study highlights the utility of using multiple analytical methods to identify specimens with

323 standard DNA barcoding and especially that of statistical phylogenetics.

325 Table 1. Sampling information and identification with BOLD and the maximum-likelihood

326 phylogeny

\begin{tabular}{|c|c|c|c|c|c|}
\hline Restaurant & $\begin{array}{l}\text { Menu } \\
\text { Listing }\end{array}$ & $\begin{array}{l}\text { Putative } \\
\text { Genus }\end{array}$ & $\begin{array}{l}\text { Putative } \\
\text { Species }\end{array}$ & $\begin{array}{l}\text { BOLD ID (Top } \\
\text { percent identity) }\end{array}$ & $\begin{array}{l}\text { ML COI Phylogeny ID (Bootstrap } \\
\text { support/ PP of node) }\end{array}$ \\
\hline \multirow[t]{2}{*}{$\begin{array}{l}\text { Bobby } \\
\text { Van's } \\
\text { Steakhouse }\end{array}$} & $\begin{array}{l}\text { Rock } \\
\text { Shrimp } \\
\text { Tempura }\end{array}$ & Sicyonia & brevirostris & $\begin{array}{l}\text { Litopenaeus vannamei } \\
(100)\end{array}$ & Litopenaeus vannamei $(88 / 87)$ \\
\hline & Calamari & NA & $\mathrm{NA}$ & Uroteuthis edulis (100) & Uroteuthis edulis $(98 / 100)$ \\
\hline \multirow[t]{2}{*}{$\begin{array}{l}\text { Gordon } \\
\text { Biersch }\end{array}$} & $\begin{array}{l}\text { Yellowfin } \\
\text { Tuna }\end{array}$ & Thunnus & albacares & $\begin{array}{l}\text { Thunnus albacares } \\
\text { (100), Thunnus } \\
\text { atlanticus (100), } \\
\text { Thunnus obesus (100) }\end{array}$ & Thunnus albacares (11/6) \\
\hline & $\begin{array}{l}\text { Gulf } \\
\text { Shrimp }\end{array}$ & NA & NA & $\begin{array}{l}\text { Farfantepenaeus } \\
\text { aztecus (99.85) }\end{array}$ & Farfantepenaeus aztecus $(100 / 100)$ \\
\hline $\begin{array}{l}\text { The } \\
\text { Oceanaire } \\
\text { Seafood }\end{array}$ & $\begin{array}{l}\text { Chilean } \\
\text { Seabass }\end{array}$ & Dissostichus & eleginoides & $\begin{array}{l}\text { Dissostichus mawsoni } \\
(100)\end{array}$ & Dissostichus mawsoni (99/100) \\
\hline
\end{tabular}




\begin{tabular}{|c|c|c|c|c|c|}
\hline \multicolumn{6}{|l|}{ Room } \\
\hline & $\begin{array}{l}\text { Australian } \\
\text { Barramundi }\end{array}$ & Lates & calcarifer & $\begin{array}{l}\text { Lates uwisara (100), } \\
\text { Lates calcarifer (100) }\end{array}$ & Lates calcarifer $(100 / 99)$ \\
\hline \multirow[t]{2}{*}{$\begin{array}{l}\text { Joe's } \\
\text { Seafood, } \\
\text { Prime Steak } \\
\text { and Snow } \\
\text { Crab }\end{array}$} & $\begin{array}{l}\text { Ahi Tuna } \\
\text { Tartare }\end{array}$ & Thunnus & albacares & $\begin{array}{l}\text { Thunnus alalunga } \\
\text { (100), Thunnus obesus } \\
\text { (99.83), Thunnus } \\
\text { orientalis (99.67), } \\
\text { Thunnus maccoyii } \\
\text { (99.67) }\end{array}$ & Thunnus sp. (31/9) \\
\hline & $\begin{array}{l}\text { Chilean } \\
\text { Seabass }\end{array}$ & Dissostichus & eleginoides & $\begin{array}{l}\text { Dissostichus } \\
\text { eleginoides (100) }\end{array}$ & Dissostichus eleginoides (99/99) \\
\hline \multirow[t]{2}{*}{$\begin{array}{l}\text { Legal Sea } \\
\text { Foods }\end{array}$} & $\begin{array}{l}\text { Snapper } \\
\text { Salsa Verde }\end{array}$ & Lutjanus & NA & $\begin{array}{l}\text { Lutjanus guttatus } \\
\text { (100), Lutjanus sp. } \\
\text { (100), Lutjanus } \\
\text { synagris (98.31) }\end{array}$ & Lutjanus guttatus, Lutjanus synagris $(85 / 41)$ \\
\hline & $\begin{array}{l}\text { Everything } \\
\text { Tuna }\end{array}$ & Thunnus & NA & $\begin{array}{l}\text { Thunnus obesus (100), } \\
\text { Thunnus albacares } \\
\text { (99.84) }\end{array}$ & Thunnus obesus $(61 / 52)$ \\
\hline \multirow[t]{2}{*}{$\begin{array}{l}\text { McCormick } \\
\text { and } \\
\text { Schmick's }\end{array}$} & $\begin{array}{l}\text { Sesame } \\
\text { Crusted } \\
\text { Albacore } \\
\text { Tuna }\end{array}$ & Thunnus & alalunga & $\begin{array}{l}\text { Thunnus albacares } \\
\text { (100), Thunnus } \\
\text { atlanticus (100), } \\
\text { Thunnus obesus (100) }\end{array}$ & Thunnus albacares (14/6) \\
\hline & $\begin{array}{l}\text { Pesto } \\
\text { Chilean } \\
\text { Seabass }\end{array}$ & Dissostichus & eleginoides & $\begin{array}{l}\text { Dissostichus } \\
\text { eleginoides (100) }\end{array}$ & Dissostichus eleginoides (99/99) \\
\hline
\end{tabular}

Table 2. Tested hypotheses and marginal log likelihoods used for Bayes Factors

\begin{tabular}{|c|c|c|}
\hline Restaurant & Menu Listing & Tested Hypotheses (Marginal LOG Likelihood) \\
\hline $\begin{array}{l}\text { Bobby Van's } \\
\text { Steakhouse }\end{array}$ & $\begin{array}{l}\text { Rock Shrimp } \\
\text { Tempura }\end{array}$ & $\begin{array}{l}\text { Monophyletic with Sicyonia (-6984.27), Not monophyletic with Sicyonia (-6951.31), } \\
\text { Monophyletic with Whiteleg Shrimp (-6940.03) }\end{array}$ \\
\hline $\begin{array}{l}\text { Gordon } \\
\text { Biersch }\end{array}$ & Yellowfin Tuna & $\begin{array}{l}\text { Monophyletic with Yellowfin Tuna (-5463.35), Not-Monophyletic with Yellowfin Tuna (- } \\
\text { 5471.71) }\end{array}$ \\
\hline
\end{tabular}




\begin{tabular}{|c|c|c|}
\hline $\begin{array}{l}\text { The } \\
\text { Oceanaire }\end{array}$ & Chilean Seabass & $\begin{array}{l}\text { Monophyletic with Chilean Seabass (-5532.76), Not monophyletic with Chilean Seabass (- } \\
\text { 5469.00), Monophyletic with Antarctic Toothfish (-5457.31) }\end{array}$ \\
\hline & $\begin{array}{l}\text { Australian } \\
\text { Barramundi }\end{array}$ & $\begin{array}{l}\text { Monophyletic with Australian Barramundi(-5458.50), Not monophyletic with Australian } \\
\text { Barramundi -5472.81) }\end{array}$ \\
\hline $\begin{array}{l}\text { Joe's } \\
\text { Seafood, } \\
\text { Prime Steak } \\
\text { and Snow } \\
\text { Crab }\end{array}$ & Ahi Tuna Tartare & $\begin{array}{l}\text { Monophyletic with Ahi (-5485.01), Not monophyletic with Ahi (-5472.92), Monophyletic } \\
\text { with Albacore (-5460.75) }\end{array}$ \\
\hline & Chilean Seabass & $\begin{array}{l}\text { Monophyletic with Chilean Seabass(-5460.67), Not monophyletic with Chilean Seabass(- } \\
\text { 5470.68), Monophyletic with Antarctic Toothfish (-5530.80) }\end{array}$ \\
\hline $\begin{array}{l}\text { Legal Sea } \\
\text { Foods }\end{array}$ & $\begin{array}{l}\text { Snapper Salsa } \\
\text { Verde }\end{array}$ & $\begin{array}{l}\text { Monophyletic with Lutjanus (-5432.61), Not monophyletic with Lutjanus (-5490.42), } \\
\text { Monophyletic with L. synagris (-5460.98), Monophyletic with L. guttatis (-5460.73) }\end{array}$ \\
\hline $\begin{array}{l}\text { McCormick } \\
\text { and } \\
\text { Schmick's }\end{array}$ & $\begin{array}{l}\text { Sesame Crusted } \\
\text { Albacore Tuna }\end{array}$ & $\begin{array}{l}\text { Monophyletic with Albacore (-5492.50), Not monophyletic with Albacore (-5471.55), } \\
\text { Monophyletic with Yellowfin (-5461.95) }\end{array}$ \\
\hline & $\begin{array}{l}\text { Pesto Chilean } \\
\text { Seabass }\end{array}$ & $\begin{array}{l}\text { Monophyletic with Chilean Seabass(-5460.35), Not monophyletic with Chilean Seabass(- } \\
\text { 5531.72), Monophyletic with Antarctic Toothfish (-5469.87) }\end{array}$ \\
\hline
\end{tabular}

Table 3. Character based identification for tuna species.

\begin{tabular}{|c|c|c|c|}
\hline Restaurant & Menu Listing & $\begin{array}{l}\text { Character positions (Lowenstein et al. 2009) } \\
(262,268,271,286,313,337,358,400,409,475,478,484,508,535)\end{array}$ & ID \\
\hline $\begin{array}{l}\text { Gordon } \\
\text { Biersch }\end{array}$ & Yellowfin tuna & CCCC ACGT ATTG AC & $\begin{array}{l}\text { Yellowfin tuna } \\
\text { (T. albacares) }\end{array}$ \\
\hline $\begin{array}{l}\text { Joe's Seafood, Prime } \\
\text { Steak and Snow Crab }\end{array}$ & $\begin{array}{l}\text { Ahi Tuna } \\
\text { Tartare }\end{array}$ & CTCC GCAT ATCA AT & $\begin{array}{l}\text { Albacore } \\
\text { (T. alalunga) }\end{array}$ \\
\hline
\end{tabular}




\begin{tabular}{|l|l|l|l|}
\hline Legal Sea & Everything Tuna & CCCT ACGG ATTG AC & $\begin{array}{l}\text { Bigeye tuna } \\
\text { (T. obsesus })\end{array}$ \\
\hline $\begin{array}{l}\text { McCormick and } \\
\text { Schmick's }\end{array}$ & $\begin{array}{l}\text { Sesame Crusted } \\
\text { Albacore Tuna }\end{array}$ & CCCC ACGT ATTG AC & $\begin{array}{l}\text { Yellowfin tuna } \\
\text { (T albacares })\end{array}$ \\
\hline
\end{tabular}

334 Figure 1. Maximum-likelihood phylogeny of Vertebrate COI sequences. Names of samples from

335 this study are colored according to the "target" sequences of the menu-listing. Reference

336 sequence labels include GenBank accession numbers. Sequences that are only found on BOLD

337 are labeled as such before the accession number.

338 Figure 2. Maximum-likelihood phylogeny of Invertebrate COI sequences.

\section{Acknowledgements}

341 We thank the Smithsonian's Laboratories for Analytical Biology (LAB) for lab space and

342 sequencing services and the George Washington University's Colonial One High-Performance

343 Computing Cluster for computational support.

\section{References}

347 Altschul SF, Gish W, Miller W, Myers EW, and Lipman DJ. 1990. BASIC LOCAL

348 ALIGNMENT SEARCH TOOL. Journal of Molecular Biology 215:403-410.

349 Altschul SF, Madden TL, Schaffer AA, Zhang JH, Zhang Z, Miller W, and Lipman DJ. 1997.

350 Gapped BLAST and PSI-BLAST: a new generation of protein database search programs.

$351 \quad$ Nucleic acids research 25:3389-3402. 
352 Ardura A, Linde AR, Moreira JC, and Garcia-Vazquez E. 2010. DNA barcoding for conservation 353 and management of Amazonian commercial fish. Biological Conservation 143:1438$354 \quad 1443$.

355 Brown SD, Collins Ra, Boyer S, Lefort MC, Malumbres-Olarte J, Vink CJ, and Cruickshank RH. 356 2012. Spider: an R package for the analysis of species identity and evolution, with 357 particular reference to DNA barcoding. Molecular ecology resources 12:562-565.

358 Collins Ra, and Cruickshank RH. 2013. The seven deadly sins of DNA barcoding. Molecular 359 ecology resources 13:969-975.

360 Edwards SV. 2009. IS A NEW AND GENERAL THEORY OF MOLECULAR SYSTEMATICS $361 \quad$ EMERGING? Evolution 63:1-19.

362 Elias M, Hill RI, Willmott KR, Dasmahapatra KK, Brower AV, Mallet J, and Jiggins CD. 2007.

363 Limited performance of DNA barcoding in a diverse community of tropical butterflies. 364 Proceedings of the Royal Society of London B: Biological Sciences 274:2881-2889.

365 FDA. 2011. Fish and fishery products hazards and controls guidance. US Department of Health 366 and Human Services Food and Drug Administration Center for Food Safety and Applied $367 \quad$ Nutrition.

368 Folmer O, Black M, Hoeh W, Lutz R, and Vrijenhoek R. 1994. DNA primers for amplification of 369 mitochondrial cytochrome c oxidase subunit I from diverse metazoan invertebrates. $370 \quad$ Molecular marine biology and biotechnology 3:294-299.

371 Hanner R, Becker S, Ivanova NV, and Steinke D. 2011. FISH-BOL and seafood identification:

372 Geographically dispersed case studies reveal systemic market substitution across Canada. 373 Mitochondrial DNA 22:106-122.

374 Hebert PDN, Cywinska A, Ball SL, and DeWaard JR. 2003. Biological identifications through 375 DNA barcodes. Proceedings of the Royal Society B-Biological Sciences 270:313-321.

376 Huelsenbeck JP, and Crandall KA. 1997. Phylogeny estimation and hypothesis testing using 377 maximum likelihood. Annual Review of Ecology and Systematics 28:437-466. 
378 IUCN. 2015. IUCN Red List of Threatened Species. Available at http://www.iucnredlist.org $379 \quad$ (accessed 3/29/2015 2015).

380 Ivanova NV, Zemlak TS, Hanner RH, and Hebert PD. 2007. Universal primer cocktails for fish $381 \quad$ DNA barcoding. Molecular Ecology Notes 7:544-548.

382 Kass RE, and Raftery AE. 1995. Bayes factors. Journal of the american statistical association 383 90:773-795.

384 Katoh K, and Standley DM. 2013. MAFFT multiple sequence alignment software version 7:

385 improvements in performance and usability. Molecular biology and evolution 30:772$386 \quad 780$

387 Lanfear R, Calcott B, Ho SY, and Guindon S. 2012. PartitionFinder: combined selection of 388 partitioning schemes and substitution models for phylogenetic analyses. Molecular 389 biology and evolution 29:1695-1701.

390 Lowenstein JH, Amato G, and Kolokotronis S-O. 2009. The real maccoyii: identifying tuna sushi 391 with DNA barcodes-contrasting characteristic attributes and genetic distances. PloS one $392 \quad 4: e 7866$.

393 Lowenstein JH, Burger J, Jeitner CW, Amato G, Kolokotronis SO, and Gochfeld M. 2010. DNA

394 barcodes reveal species-specific mercury levels in tuna sushi that pose a health risk to $395 \quad$ consumers. Biology letters 6:692-695.

396 Marko PB, Lee SC, Rice AM, Gramling JM, Fitzhenry TM, McAlister JS, Harper GR, and 397 Moran AL. 2004. Mislabelling of a depleted reef fish. Nature 430:309-310.

398 Metzker ML, Mindell DP, Liu X-M, Ptak RG, Gibbs Ra, and Hillis DM. 2002. Molecular 399 evidence of HIV-1 transmission in a criminal case. Proceedings of the National Academy $400 \quad$ of Sciences of the United States of America 99:14292-14297.

401 Posada D, and Crandall KA. 2001. Selecting the best-fit model of nucleotide substitution. $402 \quad$ Systematic biology 50:580-601. 
403 Ronquist F, Teslenko M, van der Mark P, Ayres DL, Darling A, Höhna S, Larget B, Liu L,

404 Suchard MA, and Huelsenbeck JP. 2012. MrBayes 3.2: efficient Bayesian phylogenetic 405 inference and model choice across a large model space. Systematic biology 61:539-542.

406 Rubenstein WB. 2004. On what a private attorney general is-and why it matters. Vanderbilt Law $407 \quad$ Review 57:2129.

408 Song H, Buhay JE, Whiting MF, and Crandall KA. 2008. Many species in one: DNA barcoding 409 overestimates the number of species when nuclear mitochondrial pseudogenes are 410 coamplified. Proceedings of the National Academy of Sciences of the United States of $411 \quad$ America 105:13486-13491.

412 Stamatakis A. 2014. RAxML version 8: a tool for phylogenetic analysis and post-analysis of large 413 phylogenies. Bioinformatics 30:1312-1313.

414 Torres Ra, Feitosa RB, Carvalho DC, Freitas MO, Hostim-Silva M, and Ferreira BP. 2013. DNA 415 barcoding approaches for fishing authentication of exploited grouper species including 416 the endangered and legally protected goliath grouper $<\mathrm{i}>$ Epinephelus itajara $</ \mathrm{i}>$. Scientia $417 \quad$ Marina 77:409-418.

418 Vandamme SG, Griffiths AM, Taylor SA, Di Muri C, Hankard EA, Towne JA, Watson M, and 419 Mariani S. 2016. Sushi barcoding in the UK: another kettle of fish. Peerj 4.

420 Ward RD, Zemlak TS, Innes BH, Last PR, and Hebert PDN. 2005. DNA barcoding Australia's 421 fish species. Philosophical Transactions of the Royal Society B-Biological Sciences $422 \quad 360: 1847-1857$.

423 Warner K, Golden R, Lowell B, Disla C, Savitz J, and Hirshfield M. 2014. Shrimp: Oceana 424 Reveals Misrepresentation of America's Favorite Seafood. Oceana, http://oceana 425 org/sites/default/files/reports/oceana_reveals_misrepresentation_of_americas_favorite_s $426 \quad$ eafood $p d f$.

427 Warner K, Timme W, Lowell B, and Hirshfield M. 2013. Oceana study reveals seafood fraud 428 nationwide. Oceana Retrieved on August 11:2014. 
429 Wong EHK, and Hanner RH. 2008. DNA barcoding detects market substitution in North $430 \quad$ American seafood. Food Research International 41:828-837.

431 Zhang AB, Muster C, Liang HB, Zhu CD, Crozier R, Wan P, Feng J, and Ward RD. 2012. A 432 fuzzy-set-theory-based approach to analyse species membership in DNA barcoding. $433 \quad$ Molecular Ecology 21:1848-1863.

434 


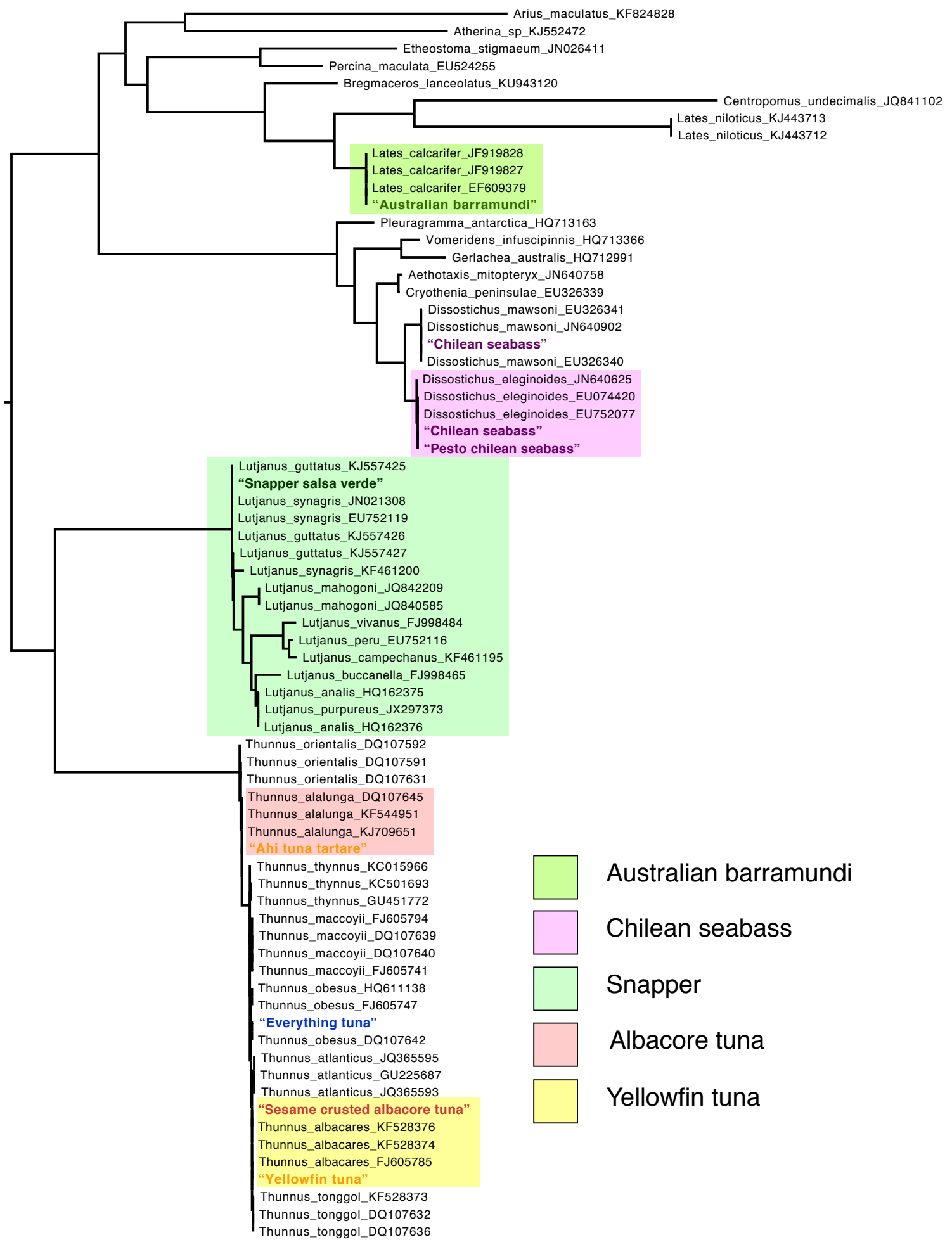




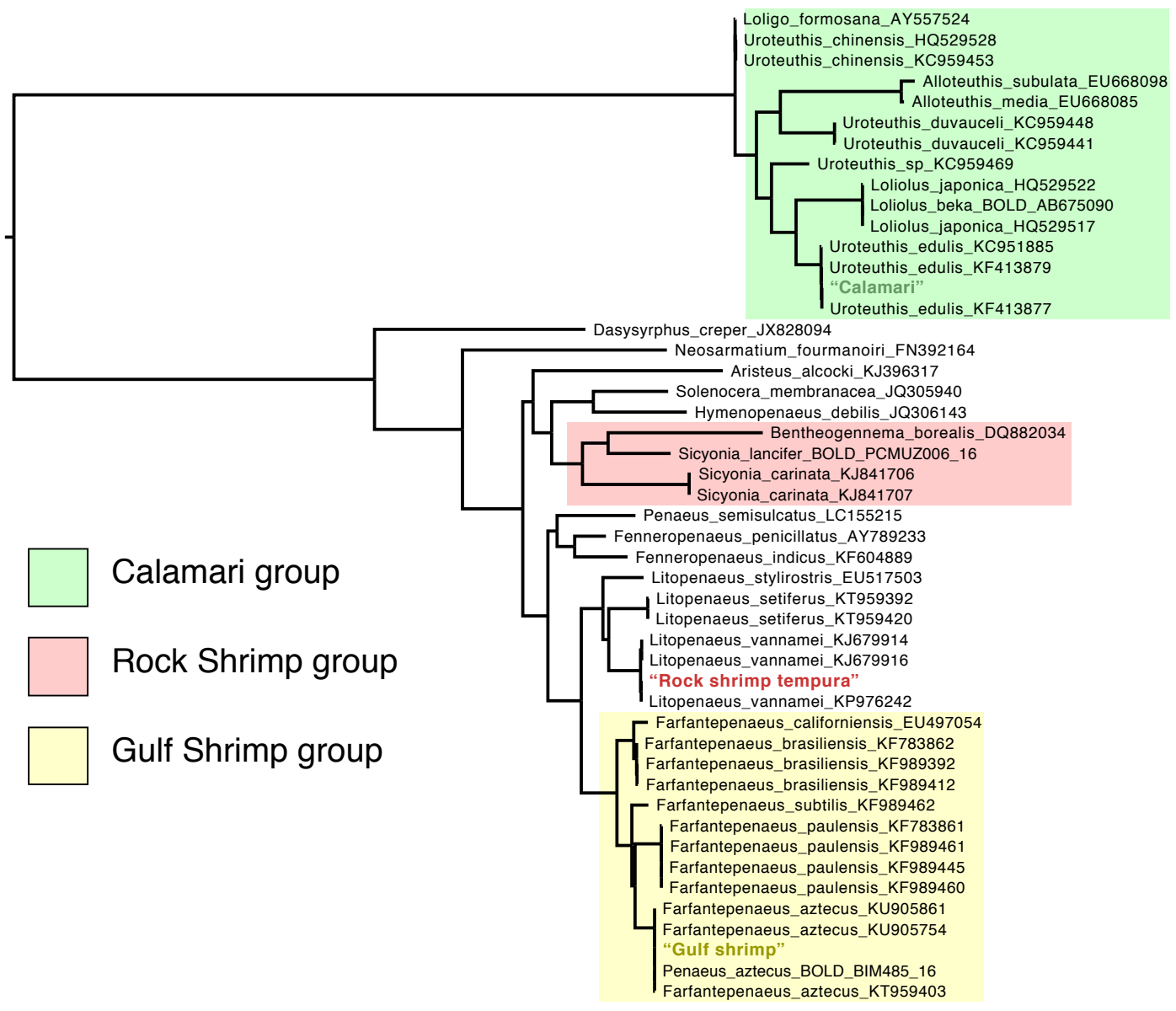

